\title{
Competing Federal Universities as a Platform for Sustainable Development of Mineral Extracting Economy
}

\author{
Andrey Voloshin ${ }^{1}$, Julia Suslova ${ }^{1}$, Svetlana Demchenko ${ }^{1, *}$, Elina Batraeva $^{1}$, Marcel \\ Batraev $^{1}$, and Samer Khouri ${ }^{2}$ \\ ${ }^{1}$ Siberian Federal University, 660075 Lida Prushinskaya St. 2, Krasnoyarsk, Russia \\ ${ }^{2}$ Technical University in Kosice, Institute of Earth Resources, Faculty of Mining, Ecology, Process \\ Control and Geotechnologies, Park Komenského 19, 042000 Košice, Slovakia
}

\begin{abstract}
In the context of the transition of mineral extractive economies to sustainable development, the role of scientific and innovative support of this process is increasing. Universities are key components of this structural breakthrough. For the Russian economy, interaction and competition between federal universities are especially important, which, on the one hand, offer new technologies of "green" mining, and on the other, they form a high-tech breakthrough. The authors of the study have analyzed the competitiveness of Russian federal universities based on a developed methodology. This allows them to identify leaders and outsiders among these educational organizations and determine their strengths and weaknesses. The results allow the authors to determine the competitiveness of federal universities based on aggregated indicators that consider the influence of internal and external environment factors. The developed and tested methodology is based on the performance indicators of educational organizations, the "Project 5-100" indicators, and the indicators of international competitiveness.
\end{abstract}

\section{Introduction}

Transition to sustainable development requires the combined efforts of universities, government and business, which is especially typical for extractive economies. The activities of federal universities in Russia are aimed at solving the strategic tasks of the state in science and education. Therefore, they should be constantly under the close attention of all interested parties. An objective, balanced assessment of competitiveness in the market of educational services is required to form a strategic policy for the development of a federal university. The formation of this assessment should be based on an integrated approach that includes factors of the internal and external environment, including the international situation, with the use of comparative analysis to identify strengths and weaknesses in relation to other federal universities.

\footnotetext{
*Corresponding author: sdemchenko@sfu-kras.ru
} 


\section{Materials and Methods}

The basis of the provided research is the analysis of the data published by federal universities on their official websites, as well as self-study reports [1-10], which ensured the objectivity of the data [11-22]. We also relied on information about the positions of federal universities in international rankings and resources of Scopus, Web of Science, and SciVal. The formation of a comprehensive view of the competitiveness of a federal university based on building the profile of the educational organization was carried out using a three-dimensional graphic image to ensure the clarity of the results obtained.

\section{Results}

From our point of view, the activities of federal universities in the interests of regions determine their specifics and structure. The global challenges facing society and the higher education system, as well as the dynamics of scientific and technological progress, put forward the role of federal universities as centers of innovative potential and development of society. Therefore, the activities of federal universities should be aimed at the production of scientific knowledge, its implementation, capacity building, and support for the innovative development of the region, country, and society.

The analysis of the competitiveness of a federal university involves the implementation of the following stages:

1. Analysis of factors of the internal and external environment of higher education institutions that form competitiveness.

2. Assessment of the achieved level of competitiveness

3. Building a competitive profile of an educational organization.

The initial stage of assessing the competitiveness of federal universities is the analysis of factors of the internal and external environment, which is presented in our study [20].

A review of the external factors of the competitiveness of federal universities allows drawing the following conclusions:

- the influence of external factors is fundamental and creates conditions for a competitive environment. Considering external factors in the strategic planning of the activities of federal universities is the main aspect of the formation of their competitiveness [13];

- the influence of external factors is individual for each federal university. Its nature is determined by the specifics of the activities of the educational organization, its scale, characteristics of the base region, etc.

- federal universities differ significantly in most indicators (in terms of scale, which determines the overall level of educational and research activities, income, economic, scientific, and human resources, educational potential, and reserves for the formation of competitiveness) $[12,14]$.

The assessment of the internal environment of federal universities leads to the following conclusions.

1. Federal universities have significant differences in the scale, amount of funding, level of development of the material and technical base, human resources, research and advanced development efficiency, etc. [16]

2. The factors of the internal environment have a decisive impact on the level of competitiveness of federal universities [13]

3. Achieving international competitiveness requires the more effective use of internal reserves, increasing the educational and human resources and research potential of federal universities.

4. Assessing the competitiveness of federal universities requires comparing the aforementioned indicators and calculating a generalized indicator of competitiveness, which 
is the next stage of the methodology [11].

The assessment of the achieved level of competitiveness is carried out using indicators grouped in the study [12]. Their study allowed assessing the factors of the internal and external environment. Summary tables of the values of the indicators are presented in the paper (Voloshin: 2017, 239-268):

- Indicators of activity of the educational organization;

- Indicators of the "Project 5-100";

- Indicators of international competitiveness.

Self-study reports from federal universities [1-3], as well as resources from Scopus, Web of Science, and SciVal, were used. Information about the position of federal universities in international rankings was obtained from the official websites of the rankings: www.shanghairanking. com, www.timeshighereducation.com, www.topuniversities.com.

The result of calculating the estimated values for the performance indicators of educational organizations, the "Project 5-100" indicators, and the indicators of international competitiveness (according to formula 1) is presented in the study [11].

$$
I_{i j}=\frac{C_{i j}}{C_{i \max }}
$$

where $I_{i j}$ is the ratio of the value of the i-th private indicator of competitiveness to the maximum value of the $i$-th indicator among the evaluated educational organizations for the $\mathrm{j}$-th educational organization;

$C_{i j}$ is the value of the $\mathrm{i}$-th private indicator of competitiveness for the $\mathrm{j}$-th educational organization;

$C_{i \max }$ is the maximum value of the $\mathrm{i}$-th indicator for educational organizations to be evaluated.

The assessment of positioning in international rankings was carried out considering the following aspects:

- no federal universities are represented in the Academic Ranking of World Universities, so all universities have a rating value of zero;

- five federal universities are represented in the Times Higher Education World University Rankings. Considering the seriousness of this achievement, the assessment was assigned a maximum value of 1.0;

- the QS BRICS ranking includes a significant number of Russian universities, including federal. Thus, the fact of being in the ranking was estimated at 0.5 , and entering the first hundred universities in the ranking was estimated at 1.0.

In the future, with an increase in the number of Russian universities in international rankings and an increase in their competitiveness, the assessment criteria can be tightened. The following federal universities of Russia were observed:

- Immanuel Kant Baltic Federal University (BFU);

- Far Eastern Federal University (FEFU);

- Kazan (Volga Region) Federal University (CasFU);

- Northern (Arctic) Federal University named after M.V. Lomonosov (NAFU);

- North-Eastern Federal University named after M.K. Ammosov (NEFU);

- North Caucasus Federal University (NCFU);

- Siberian Federal University (SFU);

- Ural Federal University named after the first President of Russia B.N. Yeltsin (UFU);

- Crimean Federal University named after V.I. Vernadsky (KFU);

- Southern Federal University (SFU).

This illustrates the flexibility of the proposed methodology [12]. 
Table 1. Values of aggregated indicators of the competitiveness of federal universities in 2019.

\begin{tabular}{|c|c|c|c|c|c|c|c|c|c|c|}
\hline Indicator name & BFU & FEFU & CaFU & NAFU & NEFU & NCFU & SbFU & UFU & KFU & SFU \\
\hline \multicolumn{11}{|c|}{ Indicators of international competitiveness } \\
\hline $\begin{array}{l}\text { Achievements in } \\
\text { science }\end{array}$ & 0.0 & 0.3 & 1.0 & 0.0 & 0.1 & 0.0 & 0.2 & 0.7 & 0.0 & 0.3 \\
\hline $\begin{array}{l}\text { Achievements in } \\
\text { education }\end{array}$ & 0.6 & 0.6 & 0.7 & 0.5 & 0.5 & 0.7 & 0.5 & 0.7 & 0.7 & 0.6 \\
\hline $\begin{array}{l}\text { Efficient use of } \\
\text { resources }\end{array}$ & 0.5 & 0.8 & 0.6 & 0.3 & 0.2 & 0.2 & 0.3 & 0.9 & 0.2 & 0.3 \\
\hline $\begin{array}{c}\text { Effective } \\
\text { personnel policy }\end{array}$ & 0.2 & 0.7 & 0.9 & 0.4 & 0.4 & 0.3 & 0.5 & 0.7 & 0.4 & 0.5 \\
\hline $\begin{array}{l}\text { Reputation of an } \\
\text { educational } \\
\text { organization }\end{array}$ & 0.4 & 0.9 & 1.0 & 0.1 & 0.4 & 0.2 & 0.7 & 1.0 & 0.0 & 0.8 \\
\hline \multicolumn{11}{|c|}{ Parameters of the Project "5-100" } \\
\hline $\begin{array}{l}\text { Conducting } \\
\text { scientific research } \\
\text { at the } \\
\text { international level }\end{array}$ & 0.3 & 0.3 & 0.7 & 0.1 & 0.2 & 0.1 & 0.3 & 0.9 & 0.1 & 0.2 \\
\hline $\begin{array}{l}\text { International } \\
\text { recognition }\end{array}$ & 0.1 & 0.3 & 0.6 & 0.0 & 0.0 & 0.1 & 0.2 & 0.6 & 0.2 & 0.6 \\
\hline $\begin{array}{l}\text { Educational } \\
\text { environment }\end{array}$ & 0.6 & 0.6 & 0.9 & 0.4 & 0.5 & 0.7 & 0.6 & 0.8 & 0.5 & 0.8 \\
\hline \multicolumn{11}{|c|}{ Indicators of activity of the educational organization } \\
\hline $\begin{array}{l}\text { Educational } \\
\text { activities }\end{array}$ & 0.4 & 0.5 & 0.7 & 0.3 & 0.4 & 0.5 & 0.7 & 0.9 & 0.7 & 0.7 \\
\hline $\begin{array}{l}\text { Research } \\
\text { activities }\end{array}$ & 0.3 & 0.4 & 0.6 & 0.3 & 0.2 & 0.3 & 0.4 & 0.7 & 0.2 & 0.3 \\
\hline $\begin{array}{l}\text { International } \\
\text { activities }\end{array}$ & 0.3 & 0.5 & 0.6 & 0.3 & 0.2 & 0.1 & 0.1 & 0.3 & 0.2 & 0.2 \\
\hline $\begin{array}{l}\text { Financial and } \\
\text { economic } \\
\text { activities }\end{array}$ & 0.5 & 1.0 & 0.5 & 0.3 & 0.4 & 0.3 & 0.4 & 0.7 & 0.3 & 0.4 \\
\hline $\begin{array}{l}\text { Infrastructure } \\
\text { health }\end{array}$ & 0.5 & 0.8 & 0.7 & 0.8 & 0.7 & 0.6 & 0.4 & 0.6 & 0.6 & 0.8 \\
\hline
\end{tabular}

The values of the aggregated indicators of the competitiveness of federal universities, calculated according to formula 2 given in the study [11], are presented in Table 1.

$$
C_{i j}{ }^{A}=\frac{1}{n} \times \sum_{i=1}^{n} I_{i j}
$$

where $C_{i j}{ }^{A}$ is the value of the aggregated competitiveness indicator for the $\mathrm{j}$-th 
educational organization;

$I_{i j}$ is the ratio of the value of the $\mathrm{i}$-th private indicator of competitiveness to the maximum value of the $\mathrm{i}$-th indicator among the evaluated educational organizations for the $\mathrm{j}$-th educational organization.

According to the methodology described in the study [11], the next stage of assessing the competitiveness of federal universities was the ranking of the aggregated indicators in Table 1 by the degree of significance. For this purpose, a survey of Rosobrnadzor experts was conducted, the results of which are given in the paper [11]. The found weighted values of the aggregated indicators of competitiveness (the level of international competitiveness, the level of competitiveness in terms of the "Project 5-100", and competitiveness in terms of performance of educational organizations) are collected in the study [12].

Federal universities are ranked in Table 2 according to the value of the generalized competitiveness indicator, which is calculated according to formula 3 [12].

$$
C_{s}=\frac{1}{n} \times \sum_{i=1}^{n} \mathrm{C}_{a}
$$

The following abbreviations were used: IC - International competitiveness, CS 5-100 Competitiveness in terms of "Project 5-100" indicators, CPEO - Competitiveness in terms of performance indicators, SI - Summarizing indicator of competitiveness.

Table 2. Values of competitiveness indicators of federal universities.

\begin{tabular}{|c|c|c|c|c|}
\hline $\begin{array}{c}\text { Federal } \\
\text { University }\end{array}$ & IC & $\begin{array}{c}\text { CS } \\
\mathbf{5 - 1 0 0}\end{array}$ & CPEO & SI \\
\hline UFU & 0.83 & 0.78 & 0.73 & 0.780 \\
\hline CaFU & 0.89 & 0.76 & 0.68 & 0.775 \\
\hline FEFU & 0.70 & 0.44 & 0.64 & 0.592 \\
\hline SFU & 0.58 & 0.53 & 0.49 & 0.532 \\
\hline SbFU & 0.48 & 0.39 & 0.48 & 0.449 \\
\hline DFU & 0.38 & 0.33 & 0.42 & 0.377 \\
\hline CFU & 0.26 & 0.27 & 0.45 & 0.330 \\
\hline NAFU & 0.29 & 0.27 & 0.41 & 0.326 \\
\hline NEFU & 0.35 & 0.24 & 0.38 & 0.321 \\
\hline NAFU & 0.26 & 0.20 & 0.40 & 0.284 \\
\hline
\end{tabular}

The presence of reserves at the Ural Federal University to increase international competitiveness did not prevent it from taking first place in the ranking, outstripping the Kazan (Volga region) Federal University in terms of the "Project 5-100" indicators and performance indicators of the educational organization. The latter's second place is due to the high publication activity, achievements in education, and a relatively high level of international cooperation. The third line of the ranking belongs to the Far Eastern Federal University. Despite the fairly high values of the performance indicators of the self-study report and the level of international cooperation, it failed in terms of the "Project 5-100". 
The remaining federal universities show a significant gap from the top three. The generalized indicator of competitiveness allows dividing federal universities into three groups.

The first group (with an indicator value from 0.59 to 1.0 ) includes the leaders listed earlier.

The second group includes federal universities with an index level from 0.449 to 0.58 . It includes the Southern Federal ( 0.532 - fourth place) and Siberian Federal ( 0.449 - fifth place) universities.

The third, with a serious gap from the first two groups, is formed by the remaining federal universities. The value of the overall competitiveness indicator below $50 \%$ of the ranking indicates the presence of serious reserves for their improvement and the need to develop a program for the formation of their competitiveness.

Figures 1-4 show the ranking of federal universities by the value of competitiveness indicators calculated by functional groups.

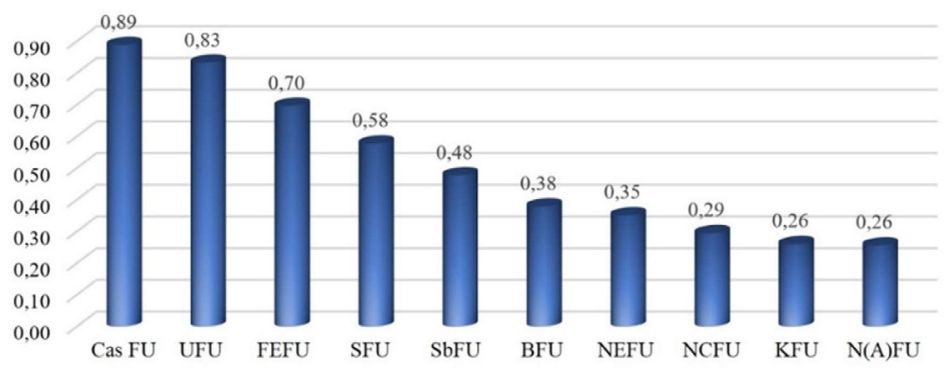

Fig. 1. Ranking of Russian universities by the level of international competitiveness in 2019 .

Comparison of the data in Figure 1 with Table 2 shows changes in the ranking, expressed in the leading positions in terms of international competitiveness of the Kazan (Volga Region) Federal University. The second place in the ranking is taken by the Ural Federal University.

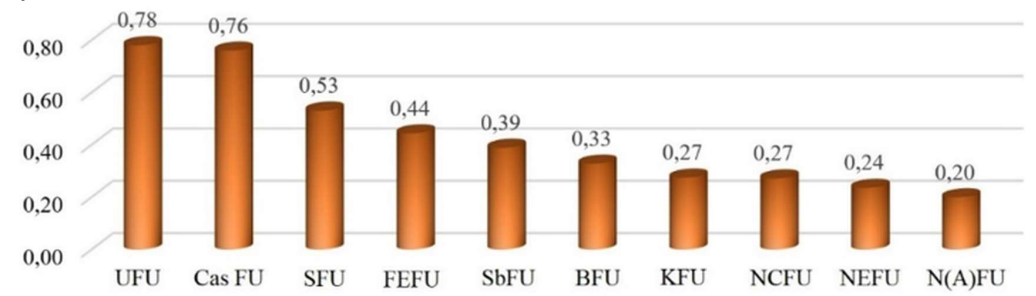

Fig. 2. Ranking of federal universities by the level of competitiveness calculated based on the "Project 5-100" indicators in 2019

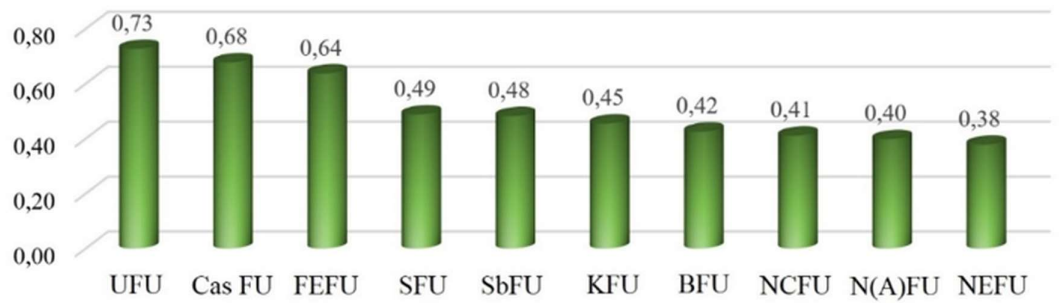

Fig. 3. Ranking of federal universities by the level of competitiveness, calculated based on the performance indicators of self-study in 2019. 
In comparison with Table 2 in Figure 2, the third place in the ranking of the Southern Federal University and, accordingly, the fourth position of the Far Eastern University attract attention. This is despite the fact that Southern, unlike the Far Eastern Federal University, is not a member of the "Project 5-100".

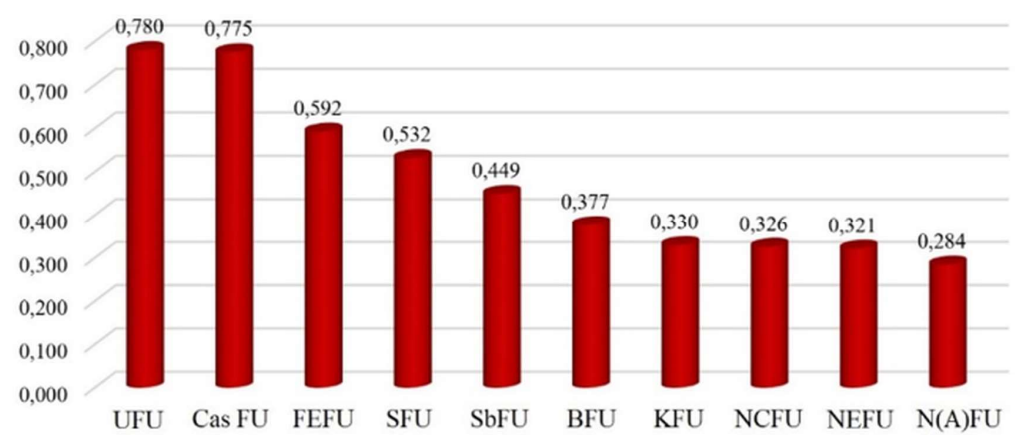

Fig. 4. Ranking of federal universities by the level of the generalized indicator of competitiveness in 2019.

The level of competitiveness calculated according to the performance indicators of the educational organization subject to self-study shows the same top three as Table 2. The second group of universities also did not change their position in the ranking. A surprise is the leadership of the Crimean Federal University in the third group, which indicates the presence of a high potential for quality growth.

The data presented in Figures 1-4 indicate a significant gap between the top three and the rest of the federal universities, which confirms the conclusions drawn from the analysis of internal and external environmental factors. The ranking of federal universities by the level of the generalized indicator of competitiveness is shown in Figure 4.

The results of the study conducted suggest that the final stage of assessing the competitiveness of federal universities is the construction of a competitiveness profile (Figure 5) based on the following indicators (where IC - the level of international competitiveness, CPEO - the level of competitiveness in terms of the performance of educational organizations, CS for "5-100" - the level of competitiveness in terms of "Project 5-100"):

- level of international competitiveness;

- level of competitiveness assessed by the "Project 5-100" indicators;

- level of competitiveness assessed by the performance indicators of educational organizations subject to self-assessment. 

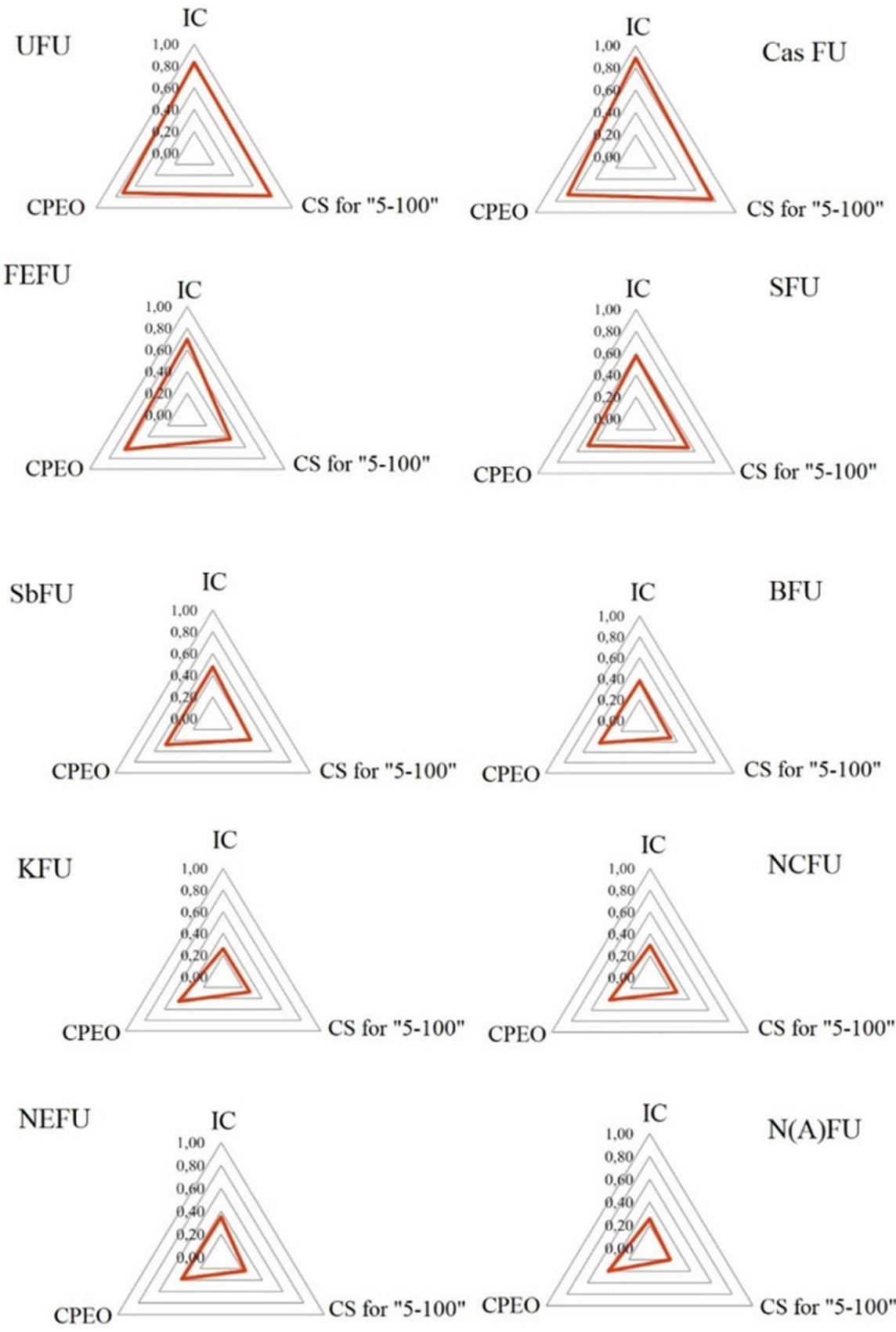

Fig. 5. Profile of the competitiveness of federal universities.

The profile presented in Figure 5 demonstrates the competitiveness of federal universities in all three groups of indicators and allows for a comprehensive assessment of their situation. 


\section{Conclusion}

The study's assessment of the competitiveness of federal universities for international competitiveness, competitiveness in terms of the "Project 5-100", and competitiveness in terms of the activities of educational organizations subject to self-study revealed the following. The top three in terms of international competitiveness includes the Kazan (Volga Region), Ural, and Far Eastern federal universities. The competitiveness assessed in terms of the "Project 5-100" gives the leadership to the Ural Federal University, shifting the Kazan (Volga Region) to the second position of the ranking and leaving the third place for the Southern Federal University. The calculation of competitiveness in terms of the performance of an educational organization leaves the first two lines of the ranking unchanged, and the Far Eastern Federal University returns to third place.

The ranking of federal universities by the value of the generalized indicator of competitiveness establishes the next three leaders: the Ural Federal University by a small margin, the Kazan (Volga Region) Federal University, and the Far Eastern Federal University.

The remaining federal universities show a significant gap from the top three. The generalized indicator of competitiveness allows dividing federal universities into three groups.

The first group (with an indicator value from 0.59 to 1.0 ) includes the leaders listed earlier.

The second group includes federal universities with an index level from 0.449 to 0.58 . It includes the Southern Federal (0.532 - fourth place) and the Siberian Federal $(0.449$ - fifth place) universities.

The third, with a serious gap from the first two groups, is formed by the remaining federal universities. The value of the overall competitiveness indicator below $50 \%$ of the ranking indicates the presence of serious reserves for improvement and the need to develop a program for the formation of the competitiveness of these organizations.

\section{References}

1. Kazan (Volga Region) Federal University, A self-report study for 2018 and 2019. URL: https://kpfu.ru/sveden/document/

2. Northern (Arctic) Federal University named after M.V. Lomonosov, A self-report study for 2018 and 2019. URL: https://narfu.ru/sveden/document/

3. Siberian Federal University, A self-report study for 2018 and 2019. URL: http://www.sfukras.ru/sveden/document

4. Far Eastern Federal University, $A$ self-study report for 2018 and 2019. URL: https://www.dvfu.ru/sveden/document/

5. North Caucasus Federal University, A self-study report for 2018 and 2019. URL: https://www.ncfu.ru/sveden/document/

6. North-Eastern Federal University named after M.K. Ammosov, A self-study report for 2018 and 2019. URL: https://www.s-vfu.ru/universitet/information/

7. Southern Federal University, $A$ self-study report for 2018 and 2019. URL: https://sfedu.ru/www/stat_pages22.show?p=GOV/N11521/B

8. Crimean Federal University named after V.I. Vernadsky, A self-study report for 2018 and 2019. URL: https://cfuv.3nv.ru/sveden/document/

9. Immanuel Kant Baltic Federal University, A self-study report for 2018 and 2019. URL: https://kantiana.ru/sveden/document/. 
10. Ural Federal University named after the first President of Russia B.N. Yeltsin, A self-study report for 2018 and 2019. URL: https://urfu.ru/sveden/document/

11. A.V. Voloshin, Yu.L. Aleksandrov, Fundamental Research, 9-1, 153-158 (2017)

12. A.V. Voloshin, Yu.L. Aleksandrov, Economic and Humanitarian Science, 9(308), 108-118 (2017)

13. A.V. Voloshin, Yu.L. Aleksandrov, Fundamental Research, 4-2, 330-338 (2017)

14. A.V. Karavaev, A.V. Voloshin, Yu.Yu. Suslova, Fundamental Research, 7, 84-93 (2018)

15. V. Kuimov, Y. Suslova, E. Shcherbenko, Mediterranean Journal of Social Sciences, 6(4), 345-351 (2015)

16. R.M. Nizhegorodtsev, S.D. Reznik, Higher education in Russia: challenges of the time and a look into the future (Infra-M, Moscow, 2020)

17. O.V. Ruban, A.V. Voloshin, J.J. Suslova N.V., Ananeva L.I. Podachina, Journal of Advanced Research in Law and Economics, 11(4), 1367-1375 (2020)

18. J.J. Suslova, T.P. Satcuk, European Journal of Science and Theology, 11(1), 233-240 (2015)

19. A.V. Voloshin, Formation of a mechanism for increasing the competitiveness of higher education organizations in the educational services market: thesis (SFU, Krasnoyarsk, 2017)

20. A.V. Voloshin, Yu.L. Aleksandrov, Fundamental Research, 12-1, 181-186 (2017)

21. A.V. Voloshin, J.J. Suslova, E.A. Batrayeva, L.V. Baguzova, N.V. Ananeva, European Research Studies Journal, 21(4), 502-511 (2018)

22. S. Zhironkin, A. Voloshin, O. Zhironkina, S. Vöth, G. Kayachev, E3S Web of Conferences, 174, $04011(2020)$ 